It must always be remembered that the forecasts are drawn for districts, not for individual stations ; and disregarding the amount of correctness claimed by the Office by its own checking of its work, they attain a very creditable amount of success when tested by independent observers. This happens even in the summer-time, the very season at which a recent critic said that the forecasts for one month, if shuffled about, and drawn at random from a bag, would suit just as well for the next! This is proved by the results of the hay harvest forecasts, which are deduced from the reports of the recipients, practical agriculturists.

The following is the table for the season of 1888 , the latest for which the figures are available :-

\begin{tabular}{|c|c|c|c|c|c|}
\hline \multirow[b]{2}{*}{ Districts. } & \multirow[b]{2}{*}{ Names of stations. } & \multicolumn{4}{|c|}{ Percentages. } \\
\hline & & 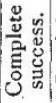 & 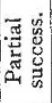 & 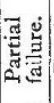 & సี \\
\hline $\begin{array}{cccc}\text { Scotland, } & \text { N. } & \ldots & \ldots \\
, & \text { E. } & \ldots & \ldots \\
& & & \cdots\end{array}$ & $\begin{array}{l}\text { Golspie and Munlochy } \ldots ̈ \ldots \\
\text { North Berwick, Glamis, Aberfeldy, }\end{array}$ & 48 & 34 & $x_{7}$ & I \\
\hline England, N.E. $\underset{\text { E..... }}{ }$ & $\begin{array}{ccccc}\text { and Rothiemay } & \ldots & \ldots & \ldots & \ldots \\
\text { Chatton and Ulceby } & \ldots & \ldots & \ldots\end{array}$ & $\begin{array}{l}43 \\
50\end{array}$ & $\begin{array}{l}41 \\
27\end{array}$ & $\begin{array}{l}\text { II } \\
\text { I7 }\end{array}$ & $\begin{array}{l}5 \\
6\end{array}$ \\
\hline 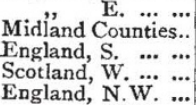 & $\begin{array}{l}\text { Thorpe and Rothamsted } \ldots \ldots \\
\text { Cirencester and East Retford } \quad \ldots \\
\text { Horsham, Maidstone, and Downton } \\
\text { Dumbarton, Islay, and Stranraer } \\
\text { Leyburn and Prescot } \quad \ldots \quad \ldots \quad \ldots\end{array}$ & \begin{tabular}{l|l}
48 \\
53 \\
52 \\
45 \\
57
\end{tabular} & $\begin{array}{l}39 \\
32 \\
40 \\
4 \mathrm{I} \\
24\end{array}$ & $\begin{array}{r}\text { IO } \\
9 \\
6 \\
8 \\
\text { II }\end{array}$ & $\begin{array}{l}3 \\
6 \\
2 \\
6 \\
8\end{array}$ \\
\hline $\begin{array}{cccc}\text { Ireland, } & \text { N. } & \ldots & \ldots \\
, " & \text { S. } & \ldots & \ldots \\
& & & \ldots\end{array}$ & 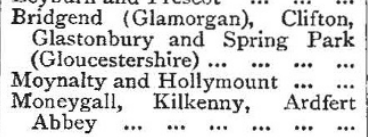 & $\begin{array}{l}46 \\
43 \\
53\end{array}$ & $\begin{array}{l}36 \\
3^{8} \\
3 x\end{array}$ & $\begin{array}{l}13 \\
14 \\
\text { Io }\end{array}$ & $\begin{array}{l}5 \\
5 \\
6\end{array}$ \\
\hline
\end{tabular}

Every year the Office hears of farmers expressing their interest in these announcements, and sending daily to the places where they are exhibited, to learn what they contain.

To give an idea of the difficulty of obtaining accurate opinions from outsiders as to the value of storm-warnings, which are a class of forecasts, it may be interesting to give some specimens of reports.

Inquiries were made in 1882 , from all the stations where signals are hoisted, as to their correctness and general utility. From Tynemouth the answer was that "these signais have been, and wili be, an inestimable boon to our seafaring population." From South Shields, just opposite Tynemouth, the reply to a recent official inquiry was that "the warnings were not a ha'porth of use, and that no one minded them." Each answer merely represented the private opinion of the person who uttered it.

The reader can see that there is some difficulty in picking out the actual truth from such a heap of incongruous statements as the foregoing are certain to furnish.

R. H. S.

\section{THE LABORATORIES OF BEDFORD} COLLEGE.

BEDFORD COLLEGE, in York Place, Baker Street, which was one of the earliest institutions devoted to the higher education of women, is taking a leading part in providing facilities for their instruction in science. Founded long before Oxford and Cambridge condescended to the "weaker sex" (which has since proved strong enough to attain to the highest place in the Classical Tripos), it is the result of the work of enthusiasts who would not admit the possibility of defeat. It has had to struggle not only against the inevitable difficulties due to its early foundation, but against the apathy of London. Provincial towns feel that their honour is involved in the success of their institutions. The Colleges for women at Oxford and Cambridge share in the picturesque surroundings of those old homes of learning. They attract attention and interest by their situation amid scenes and traditions of which the whole English-speaking race is proud. Bedford College has had no such advantages. London institutions are regarded as either Imperial or parochial-as too large or too small to interest its citizens as such. Bedford Square compares unfavourably with the "backs," and it is impossible to regard York Place with that gush of emotion which "the High" sets free. Thus it is that, although Bedford College has been at work since 1849, and though one in every four of the whole number of women who have gained degrees of the University of London has been a student in its classes, the work of the College does not yet receive the meed of public appreciation which it has fairly earned. Bedford College is for women what University and King's Colleges are for men. It provides, within easy reach of all Londoners, an education which is tested by the severe standard of the University of London, and bears the hall-mark of success. One-third of its students are aiming at degrees, and their presence in the class-rooms, their work in the examination-hall, guarantees the quality of the teaching they receive to class-mates who do not intend to face the same ordeal. Science has for long been taught in Bedford College, but there has been a pressing need for better laboratories and class-rooms. These the Council has now provided. A new wing has been built, dedicated to the memory of the late Mr. William Shaen, who worked long and devotedly for the College. About $£ 2000$ is required to complete and fit up this building free of all debt, and Mr. Henry Tate, who had already given $£$ I 1000 to the fund, has promised to supplement it by a like amount if the Council on its part can raise the other moiety of the deficit. It is too probable that this sum will only be obtained by an exhausting effort, but surely it is not too much to hope that the public may at last appreciate the importance of promoting the higher education of women in London. In a northern manufacturing town the money would be forthcoming in a week.

As regards the laboratories, it may be sufficient to say that Dr. W. Russell, F.R.S., is the Chairman of the Council, and that they have been built under his general supervision. They appear to be in all respects suited to the purposes for which they are intended. The physical laboratory and lecture-room are on the ground floor. The former has a concrete floor, and is well lighted, partly by windows, partly by a skylight. It looks out upon East Street, and is therefore removed as far as possible from the effects of the heavy traffic in Baker Street. The chemical laboratory is at the top of the house, and opens into a class-room which is fitted with all the usual conveniences for experimental illustration.

It is surely a hopeful sign that a College for the higher education of women should now be regarded as incomplete unless it controls physical and chemical laboratories specially designed and fitted for the delivery of lectures and the performance of experiments. These Bedford College now possesses. We can only hope that it may soon possess them free of debt. The Editor of NATURE will be happy to receive and forward to the College authorities any subscriptions which may be sent to him for that purpose.

\section{STEPHEN JOSEPH PERRY, F.R.S.}

$\mathrm{N}$ the evening of January 4 a telegram from Demerara announced that there had been a successful observation of the eclipse of December 22, and that Father Perry had succumbed to dysentery.

Stephen Joseph Perry was born in London on August 26,1833 , and received his early education at Gifford Hall School. Having decided to enter the priesthood, he went 